\section{Journal of Computer Networks, Architecture and High Performance Computing}

Volume 3, Number 1, January 2021

https://doi.org/10.47709/cnahpc.v3i1.933
Submitted : 3 February 2021

Accepted: 6 February 2021

Published : 26 February 2021

\title{
Rain monitoring system for nutmeg drying based on internet of things
}

\author{
DirjaNur Ilham $^{1 *}$, Eri Satria ${ }^{2)}$, Fera Anugreni ${ }^{3)}$, Rudi Arif Candra ${ }^{4)}$, Herma NugrohoRonoAdi \\ Kusumo ${ }^{5)}$ \\ ${ }^{1) 2) 344)}$ PoliteknikAceh Selatan, Indonesia, ${ }^{5)}$ PoliteknikKota Malang, Indonesia \\ ${ }^{1)}$ dirja.poltas@gmail.com, ${ }^{2)}$ eri89rz@ gmail.com, ${ }^{3)}$ anugrenifera28@gmail.com, ${ }^{4)}$ rudiarifcandra@ gmail.com, \\ ${ }^{5)}$ hnugroho81@gmail.com
}

\begin{abstract}
One of the stages in drying the nutmeg is drying the nutmeg in the afternoon which is directly illuminated by the sun. The nutmeg owners in South Aceh is very difficult to get information about rain falling during the day if they are outside or are not in the nutmeg drying area. The process of monitoring the occurrence of rain during the drying of the nutmeg has been done manually by monitoring or seeing the state of the sky when it is cloudy. The purpose of this research is to create a rain monitoring system based on the "Internet of things" internet to make it easier for nutmeg owners to get information about rain falling from a distance. This research uses nodeMCU which functions as a controller of a rain monitoring system, a raindrop sensor as a rain detection sensor. The working system of the rain monitoring tool is by connecting the nodeMCU to the led light and if the raindrop sensor is exposed to rain then the led light will turn on or light up and the raindrop sensor reads the data point. If the data point is read 1024, it indicates that the condition is not raining, while if the data point value is $700-1023$, it indicates the condition of the drizzle, and the data point value from 0-600 indicates the heavy rain condition. The raindrop sensor sends data points to the ThingsIO.AI website as a condition notification that the nutmeg drying area is drizzling, heavy rain, or no rain. For monitoring of nutmeg drying area, it can be accessed remotely via the "website ThingsIO.AI" using smartphones and computers that are connected by the internet. Based on the results of testing the average data point delivery time is 1 minute and the value of the data point obtained is $488-1009$.
\end{abstract}

Keywords: Internet Of Things; nodeMCU; Rain Sensor; Thingsio; Arduino.

\section{INTRODUCTION}

South Aceh Regency is one of the regions that produce nutmeg. The nutmeg owners dry the nutmeg to be processed into oil. One of the stages of drying the nutmeg is drying the nutmeg in the afternoon which is directly illuminated by the sun. The nutmeg owners in South Aceh Regency still use manual methods in drying the nutmeg. The nutmegs are dried in the sun and move nutmegs when it rains. This makes it difficult for nutmeg owners to obtain information about weather conditions if they are traveling or are not in the place to dry. The rain monitoring process so far has been done manually.

The nutmeg owners need a tool or automatic monitoring system that can detect the occurrence of rain from a distance based on the internet of things. The tool used is NodeMCU which functions as a controller for the rain monitoring system and Raindrop Sensor as a rain detection sensor(Dewi, Kartikasari, \& Mursityo, 2014). The working system of the rain monitoring tool is by connecting the nodeMCU on the led light and if the raindrop sensor is exposed to rain then the led light will turn on or turn on brightly and the raindrop sensor reads the data point. If the data point is read 1024, it indicates that the condition is not raining, while if the data point value is $700-1023$, it indicates the condition of the spatter, and the data point value from 0-600 indicates the heavy rain condition. The raindrop sensor sends data points to the ThingsIO.AI website.

The purpose of this study is to provide information on how to detect weather conditions such as heavy rains, light rain, and no rain automatically from a distance through the ThingsIO.AI website that can be accessed using a laptop/smartphone connected to the internet. The tool can help the nutmeg owners monitoring the nutmeg drying.

Previous researchers have implemented a rain sensor to measure whether that is directly integrated on the website using Arduino Uno as a controller(Kurniawan, Jati, \& Mulyana, 2016). A rain detection sensor is also applied to detect the occurrence of floods based on Android(Rahajoeningoem\& Saputra, 2017). The application of the internet of things has also been carried out for heart rate monitoring(Ilham, Hardisal, Balkhaya, Candra, \& Sipahutar,

* Corresponding author

This is anCreative Commons License This work is licensed under a Creative

Commons Attribution-NoDerivatives 4.0 International License. 


\section{Journal of Computer Networks, Architecture and High Performance Computing}

Volume 3, Number 1, January 2021

https://doi.org/10.47709/cnahpc.v3i1.933
Submitted : 3 February 2021

Accepted : 6 February 2021

Published : 26 February 2021

2019)(Ilham, 2020). also applied to light control using social media applications(Candra, Ilham, Hardisal, \& Sriwahyuni, 2019).Control the infusion run out with Arduino Uno with social media apps(Candra, Saputra, Ilham, \& Setiawan, 2020). Application of Internet of Things (IoT) for Lighting Control Using a Web-Based Arduino(Artono\& Putra, 2019). Designing an Arduino-based Automatic Cocoa Fermentation Tool(Balkhaya, Ilham, Candra, \& Anugreni, 2020). control the water pump on traditional boats automatically(Ihsan, Ilham, Candra, \& Yunan, 2020). Using the Arduino Uno device to perform energy efficiency analysis on social media applications using mobile communication devices such as telephones(Hardisal, Candra, \& Ilham, 2019). Based on eleven studies that have been carried out, researchers applied a rain monitoring system on the Internet-based nutmeg drying of things using NodeMCU as a control system and Raindrop Sensor as a rain detector. The rain point data point value is directly displayed using the ThingsIO.AI website.

\section{LITERATURE REVIEW}

Previous research on the Internet of Things (IoT) based Weather Monitoring and Flood Detection System on Android by measuring several parameters including rainfall, temperature, humidity, air pressure, wind direction, and wind speed. (Rahajoeningoem \& Saputra, 2017). Make a raindrop detection tool and a set temperature to report regularly with a predetermined time (Muhamad Yusvin Mustar, 2017). Creating a microcontroller-based automatic weather monitoring device installed on the IEEE 802.11b WLAN network that reports data via the internet and also stores the data in storage memory (SD Card)(Sucipto, Djuni Hartawan, \& Setiawan, 2018). Creating a monitoring system for rain, temperature, and humidity detection that makes it easier for users based on a graphical user interface (Ardiyanto \& Mustar, 2020). Creating a Flood Early Warning System Based on Water Level, Water Discharge and Rainfall, equipped with a sensor data monitoring system(Abdullah, 2020). From some of the references above, the research we have done is to make a detection system for the level of rainfall including heavy rain, drizzle, and also detecting conditions if it does not rain in the mace nutmeg drying process.

\section{Tool Design}

\section{METHOD}

The design of an internet monitoring system based on the internet of things in drying the nutmeg is made to notify about the condition of rain using components, namely (1) Raindrop sensor functions as a sensor to detect rain falling or not outside the home, (2) NodeMCU functions as a controller from the rain monitoring system tool, where nodeMCU must be connected to the hotspot, (3) LED lights to serve as a signal for rain. To display data points on rainy conditions a ThingsIO.AI website is used to monitor whether rain falls on the raindrop sensor or not. The schematic design of the tool can be shown in Figure 1.

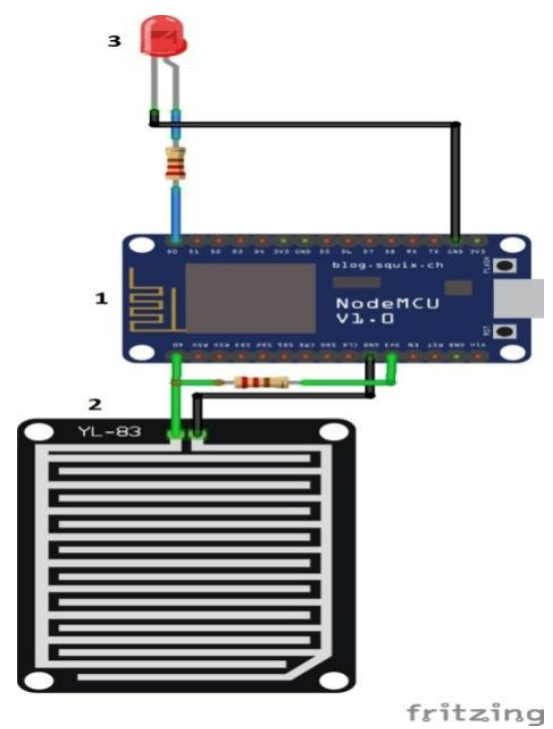

Fig.1 Schematic Tool Design 
Based on Figure 1, it can be explained that this rain monitoring system series uses 4 pins namely VCC, GND, V3, and A0 pins. The VCC pin on the rain sensor is connected to pin V3 nodeMCU. The GND pin on the raindrop sensor is connected to the GND nodeMCU pin. Pin A0 of the raindrop sensor is connected to pin A0 of nodeMCU.

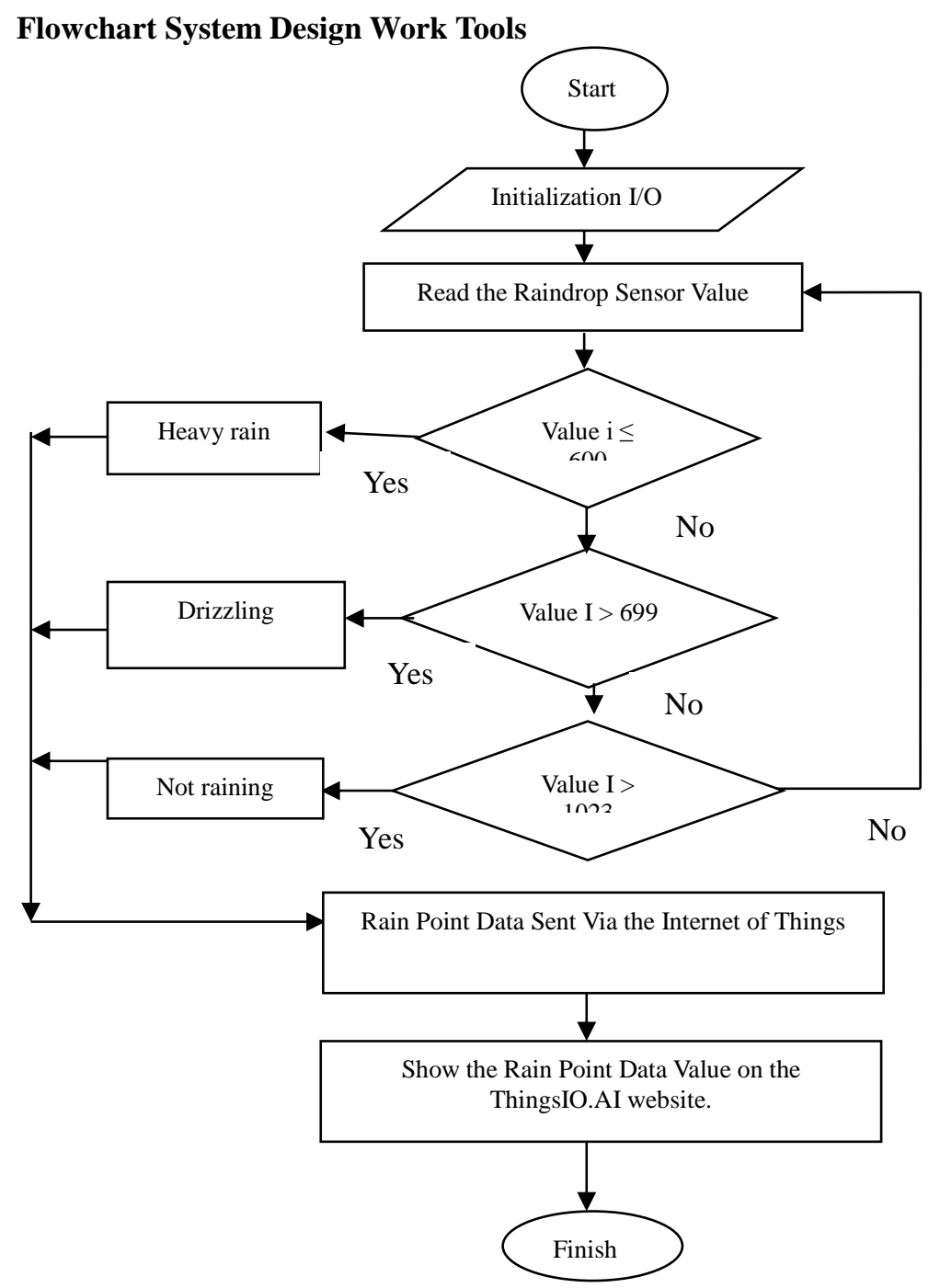

Fig. 2 Flowchart System Design Work Tools

Based on Fig. 2 it can be explained the stages of the monitoring work system. The first step is to initialize the input device and output device, the next step the raindrop sensor reads the rain condition data point value, if the value reads $\leq 600$ then the condition sent via the Internet of Things is heavy rain, then if the value is $>699$ the rain condition dries up and if the value $>1023$ then it is not raining. Sensor reading data will be sent automatically and displayed on the ThingsIO.AI website using a smartphone or laptop connected to the internet.

\section{RESULT}

Testing of rain monitoring system tools on nutmeg drying is done 10 times with different times and conditions. The testing process is done by placing the nodeMCU and led lights in the house so that they can see the condition of the LED lights on when it rains and die when it does not rain. The raindrop sensor is placed in a nutmeg drying place so that it can read the data point when rainwater hits the sensor and sends the data point via the Internet of Things to the ThingsO.AI website. The test results can be shown in table 1 and the results of the display data point conditions of 
Journal of Computer Networks, Architecture and High Performance Computing

Volume 3, Number 1, January 2021

https://doi.org/10.47709/cnahpc.v3i1.933

Submitted : 3 February 2021

Accepted : 6 February 2021

Published : 26 February 2021

heavy rain, rainfall, and non-rain can be displayed in Figures 1, 2, and 3.

Table 1. Test Results Rain Monitoring Tools on Nutmeg

\begin{tabular}{|c|c|c|c|c|c|c|}
\hline \multirow{2}{*}{ Trial } & \multirow{2}{*}{ Date } & \multicolumn{3}{|c|}{ Time } & \multirow{2}{*}{ Data Point } & \multirow{2}{*}{ Rain Status } \\
\hline & & $\begin{array}{l}\text { Led } \\
\text { life }\end{array}$ & $\begin{array}{l}\text { Data } \\
\text { Sent }\end{array}$ & $\begin{array}{l}\text { Delivery } \\
\text { Time }\end{array}$ & & \\
\hline 1 & $\begin{array}{l}\text { July-07- } \\
2019\end{array}$ & 16.45 & 16.46 & 1 Minute & 1024 & Not raining \\
\hline 2 & $\begin{array}{l}\text { July-07- } \\
2019\end{array}$ & 16.53 & 16.54 & 1 Minute & 1009 & Drizzling \\
\hline 3 & $\begin{array}{l}\text { July-10- } \\
2019\end{array}$ & 18.47 & 18.48 & 1 Minute & 994 & Drizzling \\
\hline 4 & $\begin{array}{l}\text { July-10- } \\
2019\end{array}$ & 18.55 & 18.56 & 1 Minute & 600 & Heavy rain \\
\hline 5 & $\begin{array}{l}\text { July-10- } \\
2019\end{array}$ & 19.04 & 19.05 & 1 Minute & 512 & Heavy rain \\
\hline 6 & $\begin{array}{l}\text { July-11- } \\
2019\end{array}$ & 09.00 & 09.01 & 1 Minute & 520 & Heavy rain \\
\hline 7 & $\begin{array}{l}\text { July-11- } \\
2019\end{array}$ & 11.12 & 11.13 & 1 Minute & 1024 & Not raining \\
\hline 8 & $\begin{array}{l}\text { July-12- } \\
2019\end{array}$ & 10.00 & 10.01 & 1 Minute & 970 & Drizzling \\
\hline 9 & $\begin{array}{l}\text { July-12- } \\
2019\end{array}$ & 11.00 & 11.01 & 1 Minute & 965 & Drizzling \\
\hline 10 & $\begin{array}{l}\text { July-13- } \\
2019\end{array}$ & 09.30 & 10.31 & 1 Minute & 560 & Heavy rain \\
\hline 11 & $\begin{array}{l}\text { July-13- } \\
2019\end{array}$ & 10.24 & 10.25 & 1 Minute & 500 & Heavy rain \\
\hline 12 & $\begin{array}{l}\text { July-13- } \\
2019\end{array}$ & 12.00 & 12.01 & 1 Minute & 1024 & Not raining \\
\hline
\end{tabular}

Based on Table 1 when it rains on the sensor, the LED lights on and sends data points via the internet of things. The average time for sending data points sent to the ThingsiO.AI website is 1 minute. Based on the test results, the value of the rain point data points obtained from 512-600, the data point of the spatter conditions with values of 965 1009 , and the value of the non-rain conditions remained at the value of 1024. Based on the results of the data point values obtained the lower the value of the data points read by the sensor, the higher the rainfall falls, conversely if the value of the data points obtained is high, the rainfall will be very low.

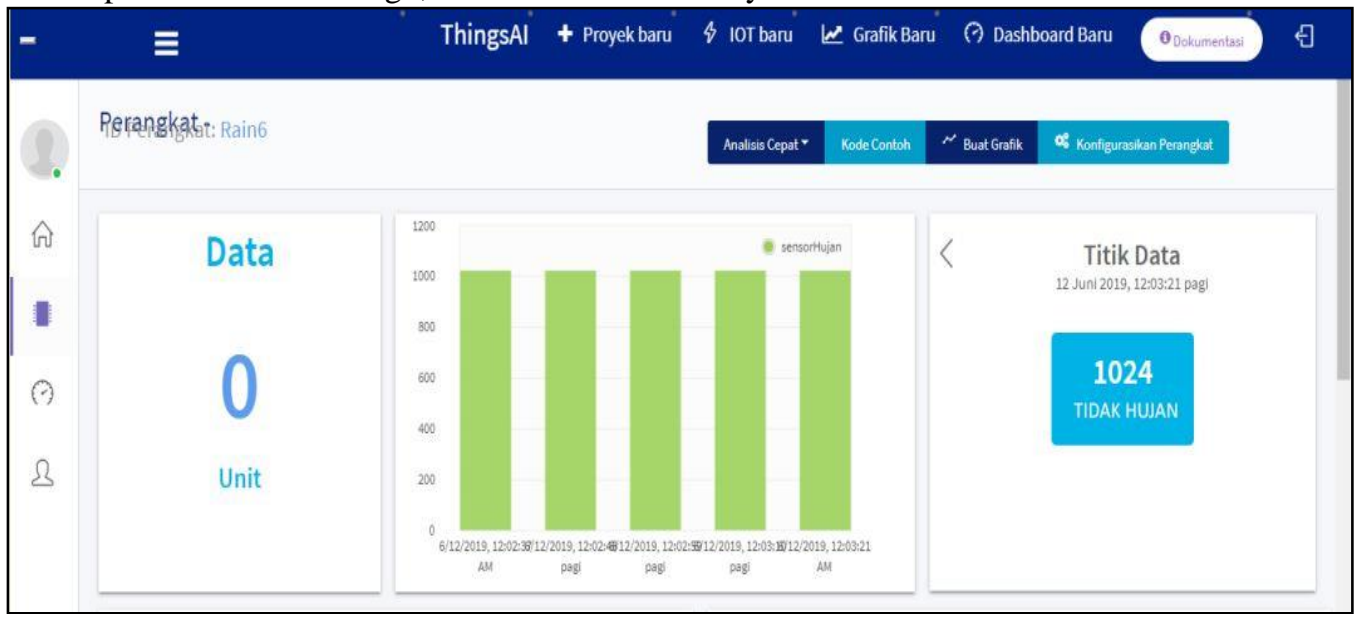

Fig. 3The Results of Displaying Conditions Not Raining on the Things.io.ai Website 
In Figure 3 the monitoring test on nutmeg drying is done in a non-rainy condition, the test is carried out at 12.02 hours by placing near the drying of nutmeg. Rain point data is sent on the ThingsiO.ai website at 12.03, the value obtained is 1024 with a description of non-rain conditions.

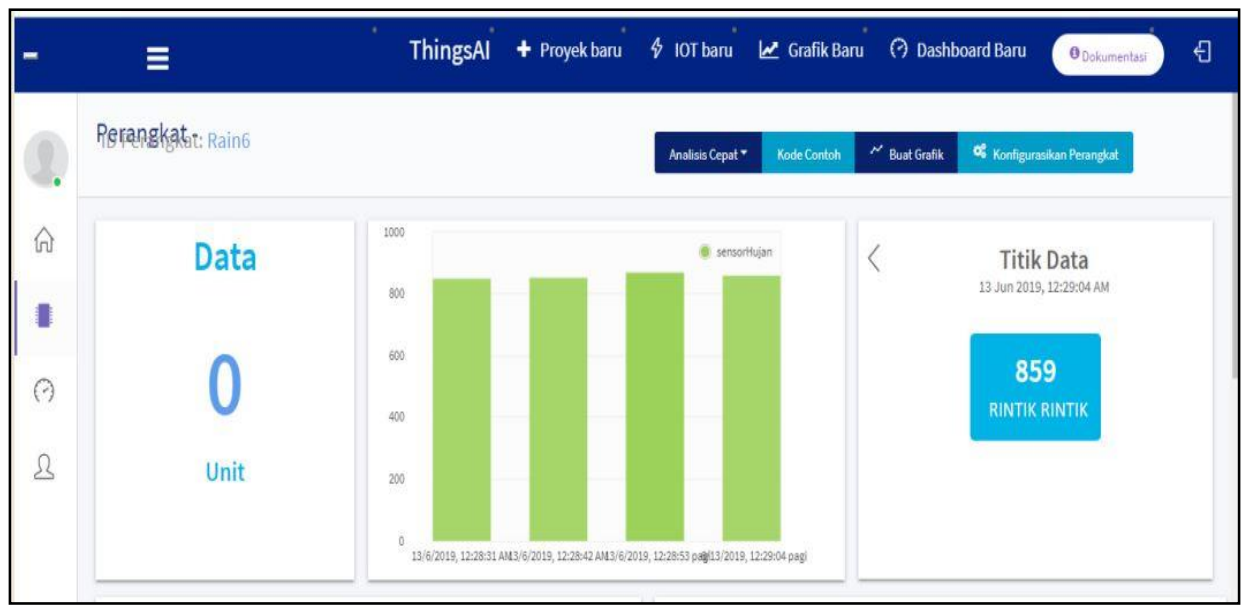

Fig. 4 Display Results of Spatter Conditions on the website Thingsio.ai

In Figure 4 the monitoring test on the drying of the nutmeg was done in the spatter conditions, the test was carried out on June 13, 2019, at 12.28 by placing the sensor near the drying of the nutmeg. Rain point data is sent on the Thingsio.AI website at 12.29 . The value obtained is 859 with a description of the spatter conditions.

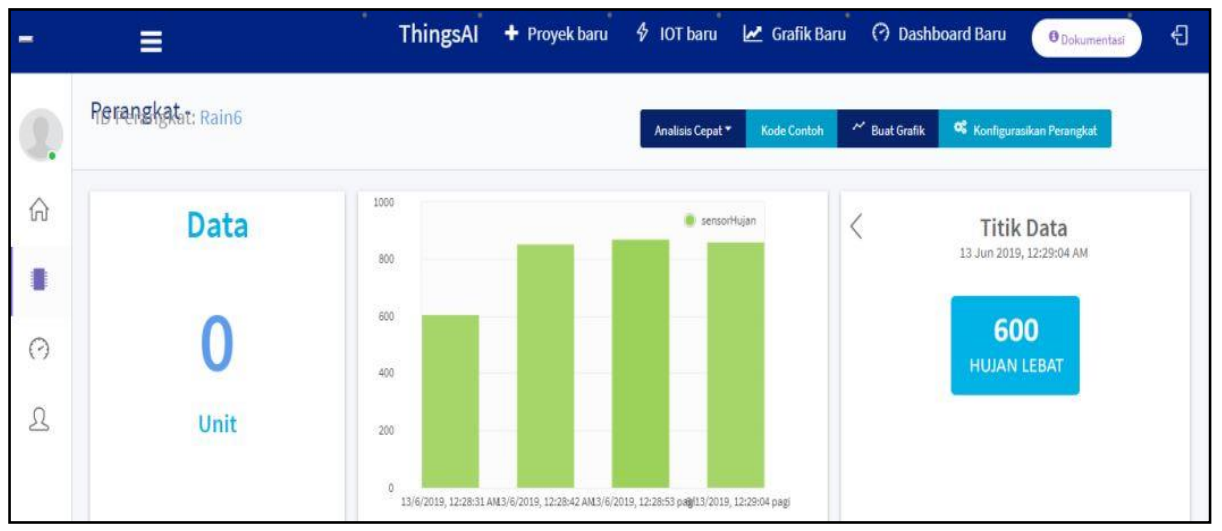

Fig. 5 Results of Display of Heavy Rain Conditions on the Thingsio.ai Website

In Figure 5 the monitoring test on nutmeg drying is done in rainy conditions, the test is carried out on June 132019 at 12.29 by placing the sensor near the drying of the nutmeg. Rain point data is sent on the ThingsiO.AI website at 12:30. The value obtained is 600 with a description of the heavy rain conditions. The results of the data point values sent on the ThingsiO.ai website will be sent in real-time. The value of the data point display will update if the rainfall conditions change.

\section{DISCUSSIONS}

Testing of the drying monitoring system was carried out using three situation variables, namely when it was not raining when it was drizzling, and during heavy rain. and the results obtained will be displayed in the ThingsiO.AI application in graphical form and from the average results shown it is clear that when the weather is not raining the 


\section{Journal of Computer Networks, Architecture and High Performance Computing}

Volume 3, Number 1, January 2021

https://doi.org/10.47709/cnahpc.v3i1.933

Submitted : 3 February 2021

Accepted : 6 February 2021

Published : 26 February 2021

drying value is higher than when it is drizzling and when it dries out the results of drying the nutmeg are still high when compared when it rains a lot.

\section{CONCLUSION}

Based on the process of making a rain monitoring tool using the internet-based raindrop sensor of things and testing 12 times in the nutmeg drying place, the conclusion is that the rain monitoring tool can detect accurately the conditions of heavy rain, light rain, and no average rain. data point delivery time is 1 minute on the Thingsio.AI website. The data point values displayed on the Thingsio.AI website are 1024 for no rain conditions, 512-600 heavy rain conditions, and 965-1009 for light rain conditions. Based on the results of the data points obtained, the lower the value of the data points read by the sensor, the higher the rainfall falls. Conversely, if the data point value is high, the rainfall is very low.

\section{REFERENCES}

Abdullah, R. F. (2020). Sistem Peringatan Dini Banjir Berdasarkan Ketinggian Air, Debit Air Dan Curah Hujan Dilengkapi Dengan Sistem Monitoring Data Sensor. 6341(April), 16-19.

Ardiyanto, Y., \& Mustar, M. Y. (2020). Rancang Bangun Graphical User Interface Sebagai Sistem Monitoring Nirkabel Pendeteksi Hujan, Suhu Dan Kelembaban. Jurnal Edukasi Elektro, 4(1), 1-11. https://doi.org/10.21831/jee.v4i1.30412

Artono, B., \& Putra, R. G. (2019). Penerapan Internet Of Things (IoT) Untuk Kontrol Lampu Menggunakan Arduino Berbasis Web. Jurnal Teknologi Informasi Dan Terapan, 5(1), 9-16. https://doi.org/10.25047/jtit.v5i1.73

Balkhaya, B., Ilham, D. N., Candra, R. A., \& Anugreni, F. (2020). Designing an Arduino-based Automatic Cocoa Fermentation Tool. 5(1), 92-99.

Candra, R. A., Ilham, D. N., Hardisal, H., \& Sriwahyuni, S. (2019). Light Control Design by Using Social Media Telegram Applications Based on Internet Of Things (IOT). SinkrOn, 3(2), 200. https://doi.org/10.33395/sinkron.v3i2.10094

Candra, R. A., Saputra, D. S., Ilham, D. N., \& Setiawan, H. (2020). The Infusion of Notification Design With an Application of Social Media Based on a Internet of Things ( IOT ). xx(xx), 129-137.

Dewi, C., Kartikasari, D. P., \& Mursityo, Y. T. (2014). Prediksi Cuaca Pada Data Time Series Menggunakan Adaptive Neuro Fuzzy Inference System (Anfis). Jurnal Teknologi Informasi Dan Ilmu Komputer (JTIIK), 1(1), 18-24.

Hardisal, H., Candra, R. A., \& Ilham, D. N. (2019). Analisis Efisiensi Energi pada Aplikasi Media Sosial Menggunakan Perangkat Komunikasi Bergerak. 9, 125-131.

Ihsan, I., Ilham, D. N., Candra, R. A., \& Yunan, A. (2020). Design of an Automatic Water Pump on a Traditional Boat. $5(1), 100-106$.

Ilham, D. N. (2020). Monitoring dan Stimulasi Detak Jantung dengan Murottal Al-Qur'an Berbasis Internet of Things (IOT). CV Jejak (Jejak Publisher).

Ilham, D. N., Hardisal, H., Balkhaya, B., Candra, R. A., \& Sipahutar, E. (2019). Heart Rate Monitoring and Stimulation with the Internet of Thing-Based (IoT) Alquran Recitation. SinkrOn, 4(1), 221. https://doi.org/10.33395/sinkron.v4i1.10392

Kurniawan, D., Jati, A. N., \& Mulyana, A. (2016). Perancangan Dan Implementasi Sistem Monitor Cuaca Menggunakan Mikrokontroler Sebagai Pendukung Sistem Peringatan Dini Banjir. E-Proceeding of Engineering, 3(1), 757-763.

Muhamad Yusvin Mustar, R. O. W. (2017). Implementasi Sistem Monitoring Deteksi Hujan dan Suhu Berbasis Sensor Secara Real Time (Implementation of Rain Detection and Temperature Monitoring System Based on Real Time Sensor). Semesta Teknika, 20(1), 20-28.

Rahajoeningoem, T., \& Saputra, I. H. (2017). Sistem Monitoring Cuaca dan Deteksi Banjir pada Android Berbasis Internet of Things (IoT). 33-40.

Sucipto, W., Djuni Hartawan, I. G. A. K. D., \& Setiawan, W. (2018). RANCANG BANGUN PERANGKAT PEMANTAU CUACA OTOMATIS BERBASIS MIKROKONTROLER PADA JARINGAN WLAN IEEE 802.11b. Jurnal SPEKTRUM, 4(2), 48. https://doi.org/10.24843/spektrum.2017.v04.i02.p07 